\title{
Effect of the inoculation level of Lactobacillus acidophilus in probiotic cheese on the physicochemical features and sensory performance compared with commercial cheeses
}

\author{
A. A. Gomes, ${ }^{\star}$ S. P. Braga, ${ }^{*}$ A. G. Cruz, ${ }^{11}$ R. S. Cadena, † P. C. B. Lollo,† C. Carvalho, ${ }^{*}$ J. Amaya-Farfán, $\dagger$ \\ J. A. F. Faria, $\dagger$ and H. M. A. Bolini† \\ *Faculdade Tecnologia Termomecânica (FTT), Curso de Tecnologia de Alimentos, 09611-900, São Bernardo do Campo, São Paulo, Brazil \\ †Universidade Estadual de Campinas (UNICAMP), Faculdade de Engenharia de Alimentos (FEA), 13083-862, Campinas, São Paulo, Brazil
}

\begin{abstract}
The complex metabolism of probiotic bacteria requires several technological options to guarantee the functionally of probiotic dairy foods during the shelf life. This research aimed to evaluate the effect of the supplementation of increasing amounts of Lactobacillus acidophilus $(0,0.4$, or $0.8 \mathrm{~g} / \mathrm{L}$ of milk) on the physicochemical parameters and sensory acceptance of Minas fresh cheese. In addition, the sensory acceptance of probiotic cheeses was assessed using a consumer test and compared with commercial cheeses (conventional and probiotic). High counts (9.11 to $9.42 \log \mathrm{cfu} / \mathrm{g}$ ) of $L$. acidophilus were observed throughout the shelf life, which contributed to the maintenance of its probiotic status and resulted in lower $\mathrm{pH}$ values and greater production of organic acids. The probiotic cheeses presented lower scores for appearance, aroma, and texture compared with conventional cheeses. Internal preference mapping explained almost $60 \%$ of the total variation of the data and showed a large number of consumers concentrated near the conventional cheeses, demonstrating greater preference for these samples. The findings indicated that some negative sensory effects could occur when high level of supplementation with L. acidophilus is used in probiotic cheese processing.

Key words: probiotic cheese, quality, sensory acceptance, internal preference mapping
\end{abstract}

\section{INTRODUCTION}

Cheese is a food consumed throughout the world and it constitutes an integral part of the diet of the population. The high calcium content is related to the maintenance of healthy bones and the presence of essential amino acids in its composition to the development of muscle structure (Ash and Wilbey, 2010); these factors

Received January 13, 2011.

Accepted May 27, 2011.

${ }^{1}$ Corresponding author: adriano@fea.unicamp.br have led to health agencies encouraging its consumption.

The supplementation of cheeses with probiotic bacteria represents the aggregation of added value to a product that already has benefits inherent in its composition. The ingestion of cheese supplemented with probiotic bacteria has been associated with a variety of benefits to human health, such as improvements in the immune system (Ibrahim et al., 2010), oral health in the elderly (Hatakka et al., 2007), and reinforcement of intestinal immunity (Medici et al., 2004) and gastrointestinal health (Modzelewska-Kapituła et al., 2010). Due to these benefits, the development of probiotic cheese is a current topic in the scientific literature (Özer and Kirmaci, 2009; Bergamini et al., 2010; Gursoy and Kinik, 2010; Obando et al., 2010; Wang et al., 2010; Awaisheh, 2011; Madureira et al., 2011a,b; Rodrigues et al., 2011) and represents a trend for the dairy industry.

Minas fresh cheese (Minas Frescal) is one of the most consumed dairy products in Brazil because of its acceptance on the national market (Pflanzer Junior et al., 2009). It is a fresh, soft, white cheese, slightly salted and with a slight lactic acid taste (Souza et al., 2008). Its potential as a functional food, especially as a food matrix to deliver different probiotic bacteria (e.g., Lactobacillus acidophilus, Lactobacillus paracasei, Bifidobacterium lactis and Bifidobacterium longum), has been reported previously (Buriti et al., 2005; Souza and Saad, 2009; Fritzen-Freire et al., 2010a). However, studies covering the changes that occur due to the addition of different levels of probiotic bacteria during processing on cheese's physicochemical parameters and sensory acceptance using commercial conventional and probiotic fresh cheeses have not been described. In this context, the present research aimed to evaluate the effect of adding increasing amounts of probiotic bacteria, particularly Lactobacillus acidophilus, on the physicochemical parameters and sensory acceptance of probiotic Minas fresh cheese. 
Table 1. Probiotic and conventional cheeses: features and codes

\begin{tabular}{lll}
\hline Cheese & Feature & Code \\
\hline Standard cheese & $0 \%(\mathrm{wt} / \mathrm{vol})$ Lactobacillus acidophilus & $\mathrm{P} 0$ \\
Probiotic cheese 1 & $0.4 \%$ (wt/vol) L. acidophilus & $\mathrm{P} 1$ \\
Probiotic cheese 2 & $0.8 \%(\mathrm{wt} / \mathrm{vol}$ L. acidophilus & $\mathrm{P} 2$ \\
Commercial cheese 1 & Absence of probiotic bacteria & $\mathrm{C} 1$ \\
Commercial cheese 2 & Absence of probiotic bacteria & $\mathrm{C} 2$ \\
Probiotic commercial cheese & Bifidobacterium animalis & $\mathrm{CP}$ \\
\hline
\end{tabular}

\section{MATERIALS AND METHODS}

\section{Probiotic Strain}

The probiotic strain used in our study was Lactobacillus acidophilus LA-5 (Chr. Hansen, Valinhos, São Paulo, Brazil). Although it is a very acidifying bacterium, recent commercial probiotic cheeses launched on the Brazilian market are using this probiotic strain (Balkis, 2011; Polengui, 2011). In this context, our research takes into account the current tendency of the Brazilian cheese industry toward probiotic dairy foods.

\section{Cheese Processing}

Cheese processing was performed in accordance with the methods described earlier (Souza and Saad, 2009; Gomes et al., 2011), with slight modifications. Eighty liters of raw milk (3.0\% fat, wt/wt) (Faculdade de Tecnologia Termomecânica, São Bernardo, São Paulo, Brazil) was pasteurized at $72^{\circ} \mathrm{C}$ for $15 \mathrm{~s}$ (model Pro110, Arpifrio, São Paulo, Brazil) and then cooled to $37^{\circ} \mathrm{C}$. Calcium chloride $(0.2 \mathrm{~g} / \mathrm{L}$; Labsynth, São Paulo, Brazil) was then added to the milk. The lactic (Lactococcus lactis R-704, 1.0\% wt/vol milk; Chr. Hansen) and probiotic (Lactobacillus acidophilus LA-5, Chr. Hansen) cultures were added in the following amounts: 0.0 (control, P0), 0.4 (P1, $10.20 \log \mathrm{cfu} / \mathrm{mL}$ ), and $0.8 \%$ (wt/ vol) milk (P2, $10.54 \log \mathrm{cfu} / \mathrm{mL})$, which correspond to $0-, 4-$, and 8-fold the concentration recommended by the manufacturer. Both cultures were freeze-dried commercial cultures for direct vat inoculation, and adequate distribution throughout the milk was achieved by manual homogenization for $2 \mathrm{~min}$. Powdered rennet (Halamix power, Chr. Hansen) was added at a concentration of $3 \mathrm{~g} / \mathrm{L}$ of milk, and the mixture was homogenized again for $2 \mathrm{~min}$. The resulting cheese-milk was kept at $37^{\circ} \mathrm{C}$ for $40 \mathrm{~min}$ to coagulate. The curd was then cut, the whey run off, and the remaining curd placed in $250-\mathrm{g}$ plastic molds. The cheeses were submitted to dry salting ( $0.8 \% \mathrm{wt} / \mathrm{vol} \mathrm{NaCl}$, Labsynth), vacuum-packaged, and stored in a cold room at 5 to $7^{\circ} \mathrm{C}$ for $20 \mathrm{~d}$. Simultaneously, full-fat commercial fresh Minas cheeses (C1 and C2) and full-fat commercial probiotic (CP) Minas fresh cheese (the only probiotic cheese available in the Brazilian market at the time of this research) were acquired from supermarkets in the city of São Paulo at the start of their shelf life, according to their labels. The cheeses were placed in Styrofoam ice-boxes and immediately transported to the laboratory, where they were also maintained in cold chambers at $5^{\circ} \mathrm{C}$ for $20 \mathrm{~d}$. Table 1 provides information about the probiotic and conventional cheeses.

\section{Physicochemical and Microbiological Analyses}

The physicochemical and microbiological analyses were carried out on d 1 and 20 after manufacture for both the commercial and probiotic cheeses (typical beginning and end of Minas fresh cheese shelf life, respectively). The processing was repeated twice and the analyses were performed in triplicate.

The $\mathrm{pH}$ values of the cheese samples were determined using a digital pH meter (B-375; Micronal Ind. Ltd., Piracicaba, Brazil) by direct insertion of the electrode into the sample (Marshall, 1993). The proteolysis extent was quantified by measuring the amino acids and peptides produced by the lactic and probiotic cultures, using a reactive solution (o-phthalaldehyde) containing the following reagents: sodium dodecyl sulfate, sodium tetraborate decahydrate, dithiothreitol, o-phthalaldehyde, and ethanol. The proteolytic extent was expressed as the absorbance of the $o$-phthalaldehyde derivatives at $340 \mathrm{~nm}$ (Masuda et al., 2005).

The levels of organic acids (lactic and acetic acids) were determined by HPLC using an Aminex X-87H column $(300 \mathrm{~mm} \times 7.8 \mathrm{~mm}$, Bio-Rad Laboratories, Richmond, CA) and a guard column with disposable cartridges $\mathrm{H}^{+}$(Bio-Rad Laboratories) maintained at $65^{\circ} \mathrm{C}$ (Ong et al., 2006). Sulfuric acid (0.009 mol/L), previously prepared by dilution with ultra-pure water obtained from a Milli-Q system (Millipore Corp., Billerica, MA) and subsequently filtered and degassed through a $0.45-\mathrm{mm}$ membrane filter (Millipore), was used as the mobile phase with a flow rate of $0.6 \mathrm{~mL} / \mathrm{min}$. A UV-visible detector was used at $220 \mathrm{~nm}$. The organic acids were quantified using standard curves prepared with solutions of the compounds of known concentrations (at least 5). Twenty-five microliters was injected 
using an automatic injector, and the chromatographic peaks were integrated using the Millenium software.

For microbiological analyses, $25 \mathrm{~g}$ of cheese was transferred into a stomacher containing $225 \mathrm{~mL}$ of sterile $0.1 \%$ (wt/vol) peptone water (Oxoid, São Paulo, Brazil). Further dilutions were made from this original dilution and the quantification of microbial counts was carried out using the pour plate technique. The starter lactococci were enumerated on M17 agar (Oxoid) and incubated under aerobic conditions at $30^{\circ} \mathrm{C}$ for $72 \mathrm{~h}$ (Ong and Shah, 2009), whereas the Lactobacillus acidophilus LA-5 count was enumerated using $0.15 \%$ bile salts-de Man, Rogosa, and Sharpe agar (Oxoid), at $37^{\circ} \mathrm{C}$ for $72 \mathrm{~h}$ under aerobic conditions (Mortazavian et al., 2007).

\section{Consumer Test}

One hundred twenty cheese consumers were recruited at random from the Faculty of Thermomechanical Technology (São Bernardo do Campo, São Paulo, Brazil) to take part in the study. The criterion for selection was the absence of allergic reactions to milk. For sensory evaluation, 6 samples were evaluated: the probiotic cheeses manufactured in the plant (P1, P2, and P3), 2 commercial full-fat cheeses purchased in grocery stores (C1 and $\mathrm{C} 2$ ), and a commercial probiotic Minas cheese recently launched on the Brazilian market, supplemented with Bifidobacterium lactis (CP).

The cheese samples were removed from the refrigerator, cut into pieces (about $1.5 \times 1.5 \times 1.5 \mathrm{~cm}$ ), and placed on white plates coded with random 3 -digit numbers $1 \mathrm{~h}$ before evaluation at room temperature $\left(25^{\circ} \mathrm{C}\right)$. The consumers were instructed to evaluate the cheese with respect to the degree of liking of the appearance, aroma, flavor, texture, and overall impression using a 9-point hybrid hedonic scale $(1=$ disliked immensely, 9 = liked immensely; Villanueva and Da Silva, 2009). Between tasting each sample, the participants were requested to eat a cream cracker biscuit and drink some spring water. The first-order and carry-over effects were balanced using a specific design, and the samples were presented monadically (MacFie et al., 1989).

\section{Statistical Analyses}

As a first step, all variables were subjected to Hartley's test to check for homogeneity of the variances within the treatments, and one-way ANOVA was then applied to the physicochemical and microbiological analysis to identify contrasts among the cheese samples. For the sensory assessment data, a 2-way ANOVA (consumers $\times$ samples) followed by Tukey's test was carried out. To compare the results from d 1 with those from d 20, the data were first subjected to the Shapiro-Wilk test to check for normality of the distribution, followed by the Student $t$-test or Mann-Whitney U-test. $P$-values < 0.05 were considered significant.

Consumer preference responses are often heterogeneous, and the mean scores may not be representative of individual opinions (Felberg et al., 2010). In this context, internal preference mapping (MDPREF) is a statistical tool that allows for the examination of individual ratings by consumers (Allgeyer et al., 2010). This method was applied to the consumer acceptance scores to examine discrimination between samples. All analyses were carried out using the Statistica 7.1 software (StatSoft, Tulsa, OK). The internal preference mapping was applied using XLSTAT software (Addinsoft, New York, NY).

\section{RESULTS AND DISCUSSION}

\section{Physicochemical Analyses}

Table 2 shows the evolution of the physicochemical characteristics of the probiotic and conventional cheeses throughout refrigerated storage. In general, changes were observed in all parameters with respect to storage time $(P<0.05)$, with evidence of the behavior that depended on the metabolism of the microbial strain used to manufacture the cheese. Indeed, although it was not possible to obtain this information from the processors, different Lactococcus strains are likely used by each dairy processor, which results in different acidification profiles during cheese processing. In addition, we observed that supplementation with increasing concentrations of $L$. acidophilus resulted in changes in the parameters $(P<0.05)$ compared with those of the commercial cheeses and commercial probiotic cheeses analyzed for each of the periods.

A decrease in $\mathrm{pH}$ values, increased proteolysis, and consequent production of organic acids is intrinsically related to the cheese manufacturing process, where the final objective is to reach the $\mathrm{pH}$ value corresponding to the isoelectric point of the caseins such that the gel coagulates. For cheeses processed by enzymatic coagulation, this is obtained by the lactic culture consuming the lactose and producing lactic acid, and for cheeses processed by direct acidification, this is obtained by the addition of organic acids (Everett and Auty, 2008). Cheeses processed with Bifidobacterium strains present an additional production of acetic acid due to their metabolism (Grattepanche et al., 2008).

In the present work, all cheeses were processed by enzymatic coagulation, including the commercial samples, according to information provided by the manufacturers. Lower $\mathrm{pH}$ values, increased proteolysis, and greater 
Table 2. Physicochemical parameters of probiotic and conventional cheeses ${ }^{1}$

\begin{tabular}{|c|c|c|c|c|c|}
\hline Day & Cheese $^{2}$ & $\mathrm{pH}$ & Proteolysis & $\begin{array}{c}\text { Lactic acid } \\
(\mathrm{g} / 100 \mathrm{~g})\end{array}$ & $\begin{array}{c}\text { Acetic acid } \\
(\mathrm{g} / 100 \mathrm{~g})\end{array}$ \\
\hline \multirow[t]{6}{*}{1} & P0 & $5.38^{\mathrm{cd}, \mathrm{A}}$ & $0.565^{\mathrm{d}, \mathrm{B}}$ & $1.17^{\mathrm{e}, \mathrm{B}}$ & $0.13^{\mathrm{c}, \mathrm{B}}$ \\
\hline & $\mathrm{P} 1$ & $5.44^{\mathrm{c}, \mathrm{A}}$ & $0.589^{\mathrm{b}, \mathrm{A}}$ & $1.35^{\mathrm{c}, \mathrm{B}}$ & $0.15^{\mathrm{bc}, \mathrm{A}}$ \\
\hline & $\mathrm{P} 2$ & $5.31^{\mathrm{d}, \mathrm{A}}$ & $0.574^{\mathrm{c}, \mathrm{B}}$ & $1.56^{\mathrm{a}, \mathrm{B}}$ & $0.16^{\mathrm{c}, \mathrm{B}}$ \\
\hline & C1 & $5.95^{\mathrm{b}, \mathrm{A}}$ & $0.502^{\mathrm{e}, \mathrm{B}}$ & $1.24^{\mathrm{d}, \mathrm{B}}$ & $0.19^{\mathrm{b}, \mathrm{A}}$ \\
\hline & $\mathrm{C} 2$ & $5.29^{\mathrm{a}, \mathrm{A}}$ & $0.589^{\mathrm{b}, \mathrm{B}}$ & $1.13^{\mathrm{f}, \mathrm{B}}$ & $0.15^{\mathrm{bc}, \mathrm{B}}$ \\
\hline & $\mathrm{CP}$ & $6.28^{\mathrm{a}, \mathrm{A}}$ & $0.635^{\mathrm{a}, \mathrm{B}}$ & $1.46^{\mathrm{b}, \mathrm{B}}$ & $0.17^{\mathrm{a}, \mathrm{A}}$ \\
\hline \multirow[t]{6}{*}{20} & $\mathrm{P} 0$ & $5.35^{\mathrm{b}, \mathrm{A}}$ & $0.588^{\mathrm{e}, \mathrm{A}}$ & $1.87^{\mathrm{e}, \mathrm{A}}$ & $0.17^{\mathrm{bc}, \mathrm{A}}$ \\
\hline & $\mathrm{P} 1$ & $5.26^{\mathrm{c}, \mathrm{B}}$ & $0.623^{\mathrm{c}, \mathrm{A}}$ & $2.58^{\mathrm{c}, \mathrm{A}}$ & $0.17^{\mathrm{bc}, \mathrm{A}}$ \\
\hline & $\mathrm{P} 2$ & $5.22^{\mathrm{c}, \mathrm{B}}$ & $0.697^{\mathrm{b}, \mathrm{A}}$ & $2.78^{\mathrm{b}, \mathrm{A}}$ & $0.36^{\mathrm{a}, \mathrm{A}}$ \\
\hline & $\mathrm{C} 1$ & $5.65^{\mathrm{a}, \mathrm{A}}$ & $0.597^{\mathrm{de}, \mathrm{A}}$ & $2.01^{\mathrm{d}, \mathrm{A}}$ & $0.31^{\mathrm{b}, \mathrm{B}}$ \\
\hline & $\mathrm{C} 2$ & $5.01^{\mathrm{a}, \mathrm{A}}$ & $0.604^{\mathrm{d}, \mathrm{A}}$ & $1.97^{\mathrm{d}, \mathrm{A}}$ & $0.25^{\mathrm{c}, \mathrm{A}}$ \\
\hline & $\mathrm{CP}$ & $5.19^{\mathrm{c}, \mathrm{A}}$ & $0.714^{\mathrm{a}, \mathrm{A}}$ & $2.96^{\mathrm{a}, \mathrm{A}}$ & $0.26^{\mathrm{c}, \mathrm{B}}$ \\
\hline
\end{tabular}

${ }^{\mathrm{a}-\mathrm{f}}$ Means with different lowercase superscripts in the same column indicate presence of statistical difference $(P$ $<0.05)$ among treatments (cheeses).

${ }^{\mathrm{A}, \mathrm{B}}$ Means with different uppercase letters in the same column indicate presence of statistical difference $(P<$ $0.05)$ between storage days.

${ }^{1}$ Analysis performed in duplicate. Proteolysis is expressed in absorbance 340 ; lactic acid and acetic acid are expressed in $\mathrm{g} / 100 \mathrm{~g}$.

${ }^{2}$ See Table 1.

production of organic acids were found in the probiotic cheeses inoculated with increasing concentrations of $L$. acidophilus (P1 and P2) and in the commercial cheese $\mathrm{CP}$, which was supplemented with $B$. animalis, at the 2 storage times analyzed throughout the storage period $(P<0.05)$. Interestingly, we also observed acetic acid production in the cheeses supplemented with increased L. acidophilus. Although Lactobacillus strains are predominantly homofermentative, they also present a heterofermentative pathway, fermenting glucose in equimolar amounts of lactic acid, $\mathrm{CO}_{2}$, and ethanol or acetic acid (Gomes and Malcata, 1999). Similar findings were found for Cheddar cheese supplemented with Lactobacillus casei, bifidobacteria, and L. acidophilus (Ong et al., 2006). On the other hand, different results were observed for a fresh probiotic Minas cheese produced by direct acidification during $28 \mathrm{~d}$ of refrigerated storage (Fritzen-Freire et al., 2010b), which is probably linked to the processing conditions (direct acidification).

Fresh cheeses, with limited refrigerated shelf life, have as their main event the primary proteolysis, which is performed by the coagulating agents and, to a lesser extent, plasmin, residual coagulants, and enzymes from the starter organisms (Sousa et al., 2001). The supplementation of cheeses with probiotic bacteria only has a relevant effect on secondary proteolysis, resulting in an increase in the total free amino acid content and the formation of compounds responsible for flavor and aroma, resulting from the catabolism of these amino acids (Cruz et al., 2009). In this way, differences between the proteolytic profiles of probiotic and conventional cheeses have only been observed in ripened cheeses, such as sheep's milk cheese (Albenzio et al., 2010), Argentinean probiotic cheese (Vinderola et al., 2009), hard and semi-hard Argentina cheeses (Bergamini et al., 2009; Milesi et al., 2009), and ovine cheese (Albenzio et al., 2010). The present study showed similar results, which could be related to the greater concentration of $L$. acidophilus used in $\mathrm{P} 1$ and $\mathrm{P} 2$ cheeses, and to the proteolytic capacity of $B$. animalis used in the manufacture of the CP cheese, suggesting the need for careful selection of the probiotic strain to be incorporated into cheeses, because alterations can be observed even in nonripened cheeses with a limited shelf life.

In addition, the mesophilic starter cultures should be compatible with the probiotic strain, and the proper ripening temperature must be used (Ziarno et al., 2010) because poor choices can influence the product's functionality due to inhibition by metabolism products, such as organic acids, peroxide, and bacteriocin, as reported previously for fermented dairy products (Vinderola et al., 2002).

\section{Microbiological Count}

Table 3 shows the evolution of the microbiological characteristics of the probiotic and conventional cheeses during refrigerated storage. In the same way, the behavior was shown to be dependent on the metabolism of the microbial strain used to manufacture the cheese and on the probiotic bacteria, for both the qualitative and quantitative aspects $(P<0.05)$. Supplementation with excessive amounts of $L$. acidophilus resulted in elevated counts of this microorganism (9.42 to $9.11 \mathrm{log}$ $\mathrm{cfu} / \mathrm{g})$, which maintained the probiotic status of the 
Table 3. Microbiological viable counts of probiotic and starter bacteria of probiotic and conventional cheeses ${ }^{1}$

\begin{tabular}{|c|c|c|c|c|}
\hline Day & Cheese $^{2}$ & $\begin{array}{c}\text { Lactococcus } \\
\text { lactis }\end{array}$ & $\begin{array}{l}\text { Lactobacillus } \\
\text { acidophilus }\end{array}$ & $\begin{array}{l}\text { Bifidobacterium } \\
\text { animalis }\end{array}$ \\
\hline \multirow[t]{6}{*}{1} & $\mathrm{P} 0$ & $8.32^{\mathrm{abcd}, \mathrm{A}}$ & - & - \\
\hline & $\mathrm{P} 1$ & $7.74^{\mathrm{cd}, \mathrm{B}}$ & $9.11^{\mathrm{b}, \mathrm{B}}$ & - \\
\hline & $\mathrm{P} 2$ & $8.11^{\mathrm{abcd}, \mathrm{A}}$ & $9.19^{\mathrm{ab}, \mathrm{B}}$ & - \\
\hline & $\mathrm{C} 1$ & $8.77^{\mathrm{ab}, \mathrm{A}}$ & - & - \\
\hline & $\mathrm{C} 2$ & $8.41^{\mathrm{abcd}, \mathrm{A}}$ & - & - \\
\hline & $\mathrm{CP}$ & $7.93^{\mathrm{bcd}, \mathrm{B}}$ & - & $8.36^{\mathrm{a}, \mathrm{A}}$ \\
\hline \multirow[t]{6}{*}{20} & P0 & $8.55^{\mathrm{abc}, \mathrm{A}}$ & - & - \\
\hline & $\mathrm{P} 1$ & $8.14^{\mathrm{abcd}, \mathrm{A}}$ & $9.31^{\mathrm{ab}, \mathrm{A}}$ & - \\
\hline & $\mathrm{P} 2$ & $8.12^{\text {abcd,A }}$ & $9.42^{\mathrm{a}, \mathrm{A}}$ & - \\
\hline & $\mathrm{C} 1$ & $8.93^{\mathrm{a}, \mathrm{A}}$ & - & - \\
\hline & $\mathrm{C} 2$ & $8.37^{\mathrm{abcd}, \mathrm{A}}$ & - & - \\
\hline & $\mathrm{CP}$ & $7.49^{\mathrm{d}, \mathrm{A}}$ & - & $8.91^{\mathrm{b}, \mathrm{B}}$ \\
\hline
\end{tabular}

\footnotetext{
${ }^{\mathrm{a}-\mathrm{d}}$ Means with different lowercase superscripts in the same column indicate presence of statistical difference $(P$ $<0.05$ ) among treatments (cheeses).

${ }^{\mathrm{A}, \mathrm{B}}$ Means with different uppercase letters in the same column indicate presence of statistical difference $(P<$ $0.05)$ between storage days.

${ }^{1}$ Analysis performed in duplicate. Microbiological analyses of Lc. lactis, Lb. acidophilus, and B. animalis are expressed in log cfu/g of cheese.

${ }^{2}$ See Table 1.
}

product throughout the shelf life. However, the count decreased during cheese manufacture, especially during whey drainage; the initial level of inoculation was around $10 \log \mathrm{cfu} / \mathrm{g}$ for both cheeses. This resulted in similar counts (around $9 \log \mathrm{cfu} / \mathrm{g}$ ) for different levels of supplementation of L. acidophilus in cheeses, and the count of this strain did not increase significantly during the cheese processing.

With respect to $B$. animalis, counts between 8.36 and $8.91 \mathrm{log} \mathrm{cfu} / \mathrm{g}$ were maintained, conferring probiotic functionality on the product. Considering that the results for the survival of probiotic bacteria in commercial cheese are limited, our present findings are noteworthy. Variations in L. lactis counts could be explained by the different strains used in the manufacture of the conventional cheeses, which possess different acidification velocities and proteolytic activities. However, differences in L. lactis counts among the probiotic cheeses were obtained: P2 presented a lower viable count compared with $\mathrm{P} 1$ and $\mathrm{P} 3$, which could be related to the different levels of addition during the cheese processing. Although efforts were made to standardize cheese manufacturing, the possibility of a small variation in the dosage level cannot be completely excluded.

Obtaining desirable therapeutic effects in probiotic lactic products such as cheeses requires the maintenance of the viability of the probiotic bacteria in sufficient amounts throughout storage of the product. Probiotic bacteria should be present in the food product in minimal amounts of $10^{6} \mathrm{cfu} / \mathrm{g}$, representing a daily dose of $10^{8} \mathrm{cfu} / \mathrm{g}$, to compensate for a possible reduction in numbers during their passage through the gastrointestinal tract (Granato et al., 2010).
Our findings indicate that $30 \mathrm{~g}$ of cheese contains about 4 billion viable probiotic cells, which is still lower than the values found in commercial fermented milks and yogurts (10 billion cells per portion). Besides, it is more practical to ingest a volume of $200 \mathrm{~mL}$ of fermented milk or yogurt compared with consuming a slice of cheese, which may explain, among other factors, the consumer preference for fermented milks or yogurts as food matrices to deliver probiotic bacteria (Hailu et al., 2009). This finding emphasizes the importance of an effective work of communication and marketing aimed to emphasize cheese as a probiotic food carrier.

Our findings confirm the potential of cheese as a food matrix to deliver probiotic microorganisms, because all samples reached the minimal value capable of conferring therapeutic benefits on the consumer. Despite the economic question covered by the increased dosage level, which most of the time is prohibitive, the probiotic count values found indicate a high probiotic density, well above the minimum requirements of many legislative organizations and it emphasizes the importance of encouraging the consumption of probiotic cheese.

The probiotic viable counts obtained were in accordance with the regulatory recommendations of several countries and regions: the Brazilian Legislation, which establishes a minimum quantity of 8 to $9 \log \mathrm{cfu} / \mathrm{g}$ (Brasil, 2008); the new Canadian legislation, which requires that a serving-size probiotic product should contain at least $9 \mathrm{log} \mathrm{cfu} / \mathrm{g}$ of the eligible microorganism (Canadian Food Inspection Agency, 2009); and finally, the European act, which requires $8 \log \mathrm{cfu} / \mathrm{g}$ for the improved lactose digestion health claim for yogurt (European Food Safety Authority, 2010). 
Indeed, cheeses have several advantages compared with fermented milks because they tend to have higher $\mathrm{pH}$ values, greater buffering capacity, a solid consistency, and relatively high protein and fat contents. These characteristics offer protection to the probiotic bacteria during storage and passage through the gastrointestinal tract (Gobbetti et al., 2010; Madureira et al., 2011a). Fresh cheese, due to its manufacturing process, appears suited to serve as a carrier for probiotic bacteria as it is an unripened cheese with a limited shelf-life under refrigeration temperatures (Cruz et al., 2009; Ouwehand et al., 2010). However, its negative characteristics are the bacteriocin production by some strains of lactococci (Ortolani et al., 2010) and the higher level of salt in some cheese varieties (Cruz et al., 2011), which can inhibit the probiotic cultures. In this context, the adoption of cheese as a food probiotic carrier should be carefully evaluated taking into account the kind of cheese chosen.

\section{Consumer Test}

Table 4 shows the scores obtained in the sensory acceptance test of the Minas fresh cheese samples. The excessive addition of probiotic microorganisms in cheese manufacture caused changes $(P<0.05)$ in the appearance, aroma, taste, and texture, resulting in reduced overall acceptance of these samples compared with the conventional commercial cheeses. Similar results were found for yogurts supplemented with excessive amounts of L. acidophilus (Olson and Aryana, 2008).

The addition of $0.8 \%$ (wt/vol) L. acidophilus in cheeses resulted in rejection by consumers with respect to taste and texture, 2 attributes with great influence on the acceptance of a food product (Martín-Diana et al., 2003; Melo et al., 2009; Palazzo and Bolini, 2009; Villanueva et al., 2010). However, when compared with the control sample (P0), the use of $0.4 \%$ (wt/vol) L. acidophilus did not result in significant sensory differences, and a suitable mean value for acceptance was obtained.
Buriti et al. (2005) also found good acceptance of Minas fresh cheese with added L. acidophilus. In other studies, with fresh or ripened cheeses with added L. acidophilus, fresh buffalo Minas cheese (Marcatti et al., 2009) and Turkish white cheese (Kasimoğlu et al., 2004), no negative effect on acceptance of the samples was observed. The addition of probiotic cultures to a food should not result in lower acceptance of the food compared with a similar conventional product (Cruz et al., 2010a), as shown in the development of various probiotic cheeses, such as Iranian white cheese produced by ultrafiltration (Zomorodi et al., 2011), Turkish Beyaz cheese (Kılıç et al., 2009), and Pategras cheese (Perotti et al., 2009).

Among the commercial brands, supplementation with $B$. animalis significantly reduced $(P<0.05)$ the acceptance of probiotic Minas fresh cheese. A possible explanation is the interaction between the $\mathrm{pH}$ values and acetic acid concentration. The lower $\mathrm{pH}$ value, allowing a greater fraction of the acetic acid in an undissociated form, increased the vinegar perception, resulting an increased acetic taste. Similar results were found in Cheddar cheese supplemented with Bifidobacterium (Ong et al., 2006). However, probiotic whey cheese supplemented with $L$. casei and B. animalis and with some other additives in its formulation showed an increase in sensory acceptance, demonstrating that the metabolism of a probiotic strain together with manipulation of the food matrix can result in a product with differentiated sensory attributes (Madureira et al., 2011b).

Internal preference mapping showed a large number of consumers concentrated near the conventional cheeses, demonstrating a greater preference for these samples and confirming the results of the consumer test (Figure 1), explaining $59.63 \%$ of the total variation of the data. A small, distinct group of consumers preferred the probiotic samples (CP, P0, P1) over the conventional cheeses, whereas P2 was the least preferred sample. Interestingly, P0 was located near P1 and far from $\mathrm{C} 1$ and $\mathrm{C} 2$ in the preference map, suggesting that

Table 4. Sensory acceptance of probiotic and conventional cheeses ${ }^{1}$

\begin{tabular}{lccccc}
\hline Cheese $^{2}$ & Appearance & Aroma & Taste & Texture & $\begin{array}{c}\text { Overall } \\
\text { acceptance }\end{array}$ \\
\hline P0 & $6.46^{\mathrm{b}}$ & $6.14^{\mathrm{cd}}$ & $5.64^{\mathrm{b}}$ & $6.03^{\mathrm{c}}$ & $6.11^{\mathrm{b}}$ \\
P1 & $5.74^{\mathrm{c}}$ & $6.04^{\mathrm{cd}}$ & $5.43^{\mathrm{b}}$ & $6.09^{\mathrm{c}}$ & $5.83^{\mathrm{bc}}$ \\
P2 & $6.16^{\mathrm{bc}}$ & $5.83^{\mathrm{d}}$ & $4.65^{\mathrm{c}}$ & $5.40^{\mathrm{d}}$ & $5.52^{\mathrm{c}}$ \\
C1 & $7.47^{\mathrm{a}}$ & $6.91^{\mathrm{ab}}$ & $6.98^{\mathrm{a}}$ & $6.83^{\mathrm{b}}$ & $7.10^{\mathrm{a}}$ \\
C2 & $7.77^{\mathrm{a}}$ & $7.23^{\mathrm{a}}$ & $7.43^{\mathrm{a}}$ & $7.55^{\mathrm{a}}$ & $7.56^{\mathrm{a}}$ \\
CP & $6.10^{\mathrm{bc}}$ & $6.56^{\mathrm{bc}}$ & $5.83^{\mathrm{b}}$ & $6.14^{\mathrm{c}}$ & $6.23^{\mathrm{b}}$ \\
\hline
\end{tabular}

${ }^{a-d}$ Mean values in the same column not followed by the same letter are significantly different $(P<0.05)$.

${ }^{1}$ Mean data from 120 consumers and based on a 9-point hedonic scale $(1=$ dislike extremely; $5=$ neither like nor dislike; 9 = like extremely).

${ }^{2}$ See Table 1. 
differences in sensory acceptance of the probiotic and conventional cheeses can also be related to the starter cultures used and to different technologies used by each cheese processor.

The addition of probiotic cultures may change the flavor or texture of the food product, sometimes in a positive way, as in the Petit Suisse cheese (Pereira et al., 2010) and probiotic goat cheese (Gomes and Mal- cata, 1998), or in a negative way such as in acerola probiotic ice cream (Fávaro-Trindade et al., 2006). Besides, repeated exposure (Luckow et al., 2005) and flavor-masking (Luckow et al., 2006) are potential and reasonable strategies to increase the sensory qualities of cheeses. Even though health claims may positively influence initial consumer interest and purchase, positive sensory acceptance is required to ensure continued

\section{Biplot (F1 and F2: $59.63 \%)$}

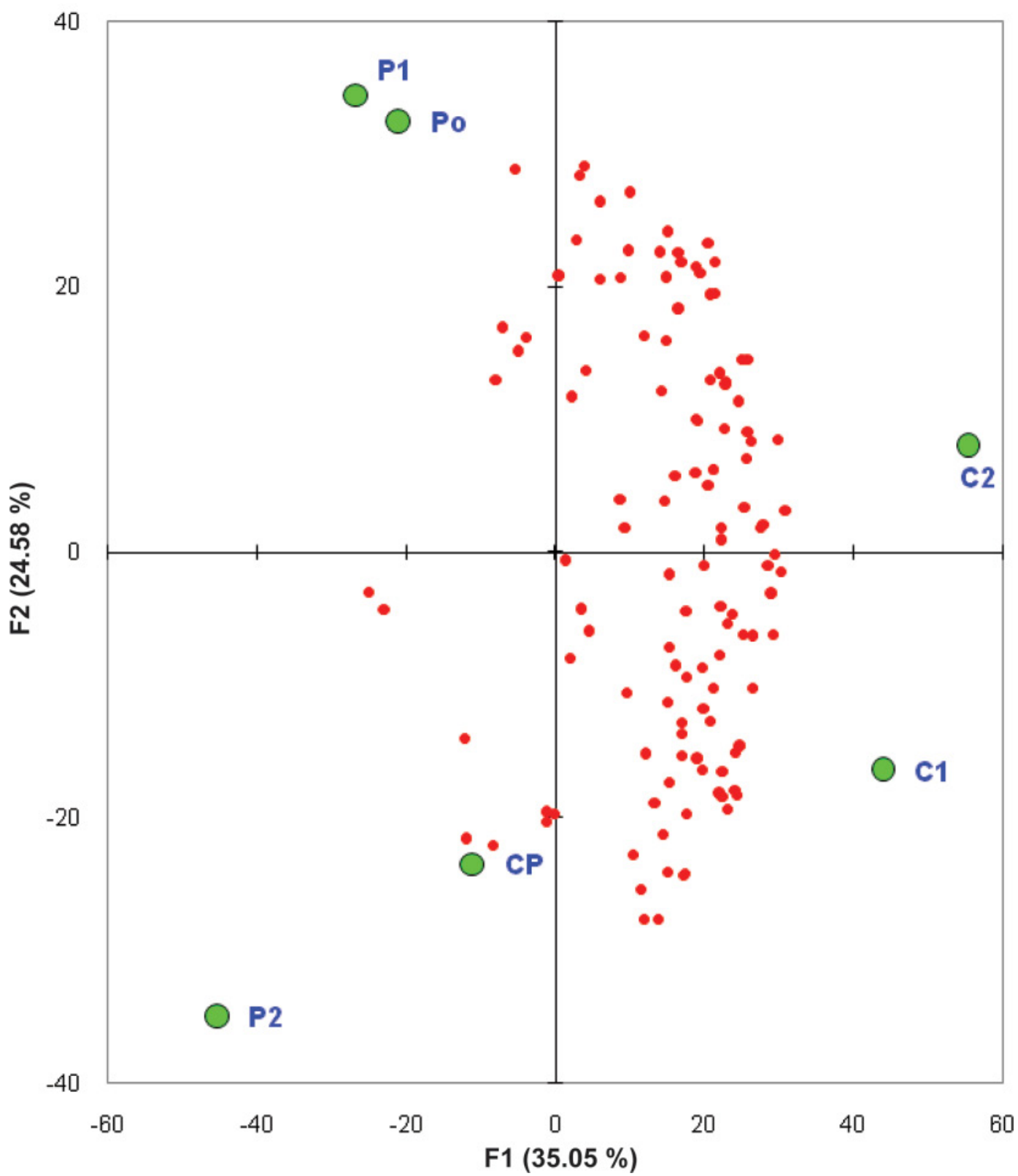

Figure 1. Internal preference mapping of probiotic and conventional cheeses. F1 and F2 = factor in the first and second dimension, respectively. For definitions of cheeses, see Table 1. Color version available in the online PDF. 
purchase. The success of a probiotic product is linked to consumer perceptions and the product's sensory properties throughout its commercial shelf life (Drake and Drake, 2011).

With regard to probiotic cheeses, satisfactory sensory performance compared with conventional commercial cheeses requires the use of probiotic bacteria with mild acidifying ability to prevent an excessive formation of acid organic and excessive proteolysis, which is linked to an adequate storage and ripening temperature to minimize the excessive bacterial growth, which would also change the flavor and texture of the final product (Karimi et al., 2011). The ideal situation is that the probiotic bacteria remain viable but not metabolically active, as reported recently with Bifidobacterium longum in Cheddar cheese (Scheller and O'Sullivan, 2011), suggesting that the probiotic cultures are suitable for fortifying cheeses without affecting their sensory properties. However, it is possible to develop probiotic dairy foods with similar acceptance and preference as conventional products (Majchrzak et al., 2010). Moreover, many nonsensory factors, such as price, brand loyalty, health claims, label, and adequacy of food carrier, are fundamental factors related to consumption of a certain food and even acceptance and, therefore, must be taken into account by cheese processors (Ares et al., 2010; Cruz et al., 2010b; Krutulyte et al., 2011).

\section{CONCLUSIONS}

The addition of increasing amounts of L. acidophilus exerted an influence on the quality parameters of the fresh probiotic Minas fresh cheese. Elevated counts of this microorganism were observed throughout storage, potentially contributing to maintenance of its probiotic status. However, the lower $\mathrm{pH}$ values and greater production of organic acids due to microbial metabolism resulted in alterations in its appearance, aroma, taste, and texture, resulting in a reduced $(P<0.05)$ acceptance of these samples compared with conventional commercial cheeses. Overall, the supplementation of fresh cheeses with excessive counts of probiotic bacteria should be carefully evaluated, taking into account technological and financial considerations.

\section{REFERENCES}

Albenzio, M., A. Santillo, M. Caroprese, R. Marino, A. Trani, and M. Faccia. 2010. Biochemical patterns in ovine cheese: Influence of probiotic strains. J. Dairy Sci. 93:3487-3496.

Allgeyer, L. C., M. J. Miller, and S.-Y. Lee. 2010. Drivers of liking for yogurt drinks with prebiotics and probiotics. J. Food Sci. 75:S212-S219.

Ares, G., A. Giménez, and R. Deliza. 2010. Influence of three non-sensory factors on consumer choice of functional yogurts over regular ones. Food Qual. Prefer. 21:11-16.
Ash, A., and A. Wilbey. 2010. The nutritional significance of cheese in the UK diet. Int. J. Dairy Technol. 63:305-317.

Awaisheh, S. S. 2011. Development of probiotic soft cheese manufactured using goat's milk with the addition of thyme. Milchwissenschaft $66: 51-54$

Balkis. 2011. Conheça melhor o queijo cottage Stimula e saiba como ele ajuda seu corpo a funcionar melhor. Accessed April 17, 2011. http:www.balkis.com.br/stimula.

Bergamini, C. V., E. R. Hynes, M. C. Candioti, and C. A. Zalazar. 2009. Multivariate analysis of proteolysis patterns differentiated the impact of six strains of probiotic bacteria on a semi-hard cheese. J. Dairy Sci. 92:2455-2467.

Bergamini, C., E. Hynes, C. Meinardi, V. Suárez, A. Quiberoni, and C. Zalazar. 2010. Pategrás cheese as a suitable carrier for six probiotic cultures. J. Dairy Res. 77:265-272.

Brasil. 2008. Alimentos com Alegações de Propriedades Funcionais e ou de Saúde, Novos Alimentos/Ingredientes, Substâncias Bioativas e Probióticos: Lista de alegacões de propriedade funcional aprovadas (Atualizado em julho/2008). Accessed April 15, 2011. http://www.anvisa.gov.br/alimentos/comissoes/tecno_lista_alega. htm.

Buriti, F. C. A., J. S. Rocha, and S. M. I. Saad. 2005. Incorporation of Lactobacillus acidophilus in Minas fresh cheese and its implications for textural and sensorial properties during storage. Int. Dairy J. $15: 1279-1288$.

Canadian Food Inspection Agency. 2009. Probiotic claims, Chapter 8, Section 8.7. Accessed April 17, 2010. http://www.inspection. gc.ca/english/fssa/labeti/guide/ch8ae.shtml.

Cruz, A. G., F. C. A. Buriti, C. B. H. Souza, J. A. F. Faria, and S. M. I. Saad. 2009. Probiotic cheese: Health benefits, technological and stability aspects. Trends Food Sci. Technol. 20:344-354.

Cruz, A. G., R. S. Cadena, E. H. M. Walter, A. Mortazavian, D. Granato, J. A. F. Faria, and H. M. A. Bolini. 2010a. Sensory analysis: Relevance for prebiotic, probiotic, and synbiotic product development. Comp. Rev. Food Sci. Food Saf. 9:358-373.

Cruz, A. G., J. A. F. Faria, M. A. R. Pollonio, H. M. A. Bolini, R. M. S. Celeghini, D. Granato, and N. P. Shah. 2011. Cheeses with reduced sodium content: Effects on functionality, public health benefits and sensory properties. Trends Food Sci. Technol. 22:276-291. doi:10.1016/j.tifs.2011.02.003.

Cruz, A. G., E. H. M. Walter, R. S. Cadena, J. A. F. Faria, H. M. A. Bolini, H. M. A. Pinheiro, and A. S. Sant'Ana. 2010b. Survival analysis methodology to predict the shelf-life of probiotic flavored yogurt. Food Res. Int. 43:1444-1448.

Drake, S., and M. Drake. 2011. Application of sensory methods to development of probiotic and prebiotic foods. Pages 113-130 in Probiotic and Prebiotic Foods: Technology, Stability and Benefits to Human Health. N. P. Shah, A. G. Cruz, and J. A. F. Faria, ed. Nova Publisher, New York, NY.

European Food Safety Authority. 2010. EFSA Panel on Dietetic Products, Nutrition and Allergies (NDA); Scientific opinion on the substantiation of health claims related to yoghurt cultures and improving lactose digestion (ID 1143, 2976) pursuant to Article 13(1) of Regulation (EC) No 1924/2006. EFSA J. 8:1763.

Everett, D. W., and M. A. E. Auty. 2008. Cheese structure and current methods of analysis. Int. Dairy J. 18:759-773.

Fávaro-Trindade, C. S., S. Bernardi, R. B. Baliero, J. C. C. Baliero, and E. Almeida. 2006. Sensory acceptability and stability of probiotic microorganisms and vitamin $\mathrm{C}$ in fermented acerola (Malpighia emarginata DC) ice cream. J. Food Sci. 71:492-495.

Felberg, I., R. Deliza, A. Farah, V. M. Calado, and C. M. Donangelo. 2010. Formulation of a soy-coffee beverage by response surface methodology and internal preference mapping. J. Sens. Stud. $25: 226-242$.

Fritzen-Freire, C. B., C. M. O. Muller, J. B. Laurindo, R. M. C. Amboni, and E. S. Prudêncio. 2010a. The effect of direct acidification on the microbiological physicochemical and sensory properties of probiotic Minas Frescal cheese. Int. J. Dairy Technol. 63:561-568.

Fritzen-Freire, C. B., C. M. O. Muller, J. B. Laurindo, and E. S. Prudêncio. 2010b. The influence of Bifidobacterium Bb-12 and lac- 
tic acid incorporation on the properties of Minas Frescal cheese. J. Food Eng. 96:621-627.

Gobbetti, M., R. Di Cagnoa, and M. De Angelis. 2010. Functional microorganisms for functional food quality. Crit. Rev. Food Sci. Nutr. 50:716-727.

Gomes, A. M. P., and F. X. Malcata. 1998. Development of probiotic cheese manufactured from goat milk: Response surface analysis via technological manipulation. J. Dairy Sci. 81:1492-1507.

Gomes, A. M. P., and F. X. Malcata. 1999. Bifidobacterium spp. and Lactobacillus acidophilus: Biological, biochemical, technological and therapeutical properties relevant for use as probiotics. Trends Food Sci. Technol. 10:139-157.

Gomes, A. P., A. G. Cruz, R. S. Cadena, R. M. S. Granato, D. Celeghini, J. A. F. Faria, H. M. A. Bolini, and M. A. R. Pollonio. 2011. Low-sodium Minas fresh cheese manufacture: Effect of the partial replacement of $\mathrm{NaCl}$ with KCl. J. Dairy Sci. 94:2701-2706.

Granato, D., G. F. Branco, A. G. Cruz, J. A. F. Faria, and N. P. Shah. 2010. Probiotic dairy products as functional foods. Comp. Rev. Food Sci. Food Saf. 9:455-470.

Grattepanche, F., S. Miescher-Schwenninger, L. Meile, and C. Lacroix. 2008. Recent developments in cheese cultures with protective and probiotic functionalities. Dairy Sci. Technol. 88:421-444.

Gursoy, O., and O. Kinik. 2010. Incorporation of adjunct cultures of Enterococcus faecium, Lactobacillus paracasei ssp. paracasei and Bifidobacterium bifidum into white cheese. J. Food Agric. Environ. 8:107-112.

Hailu, G., A. Boecker, H. Henson, and J. Cranfield. 2009. A conjoint analysis of functional foods and nutraceuticals in Canada: A conjoint study using probiotics. Appetite 52:257-265.

Hatakka, K., A. J. Ahola, H. Yli-Knuuttila, M. Richardson, T. Poussa, J. H. Meurman, and R. Korpela. 2007. Probiotics reduce the prevalence of oral Candida in the elderly-A randomized controlled trial. J. Dent. Res. 86:125-130.

Ibrahim, F., S. Ruvio, L. Granlund, S. Salminen, M. Viitanen, and A. C. Ouwehand. 2010. Probiotics and immunosenescence: Cheese as a carrier. FEMS Immunol. Med. Microbiol. 59:53-59.

Karimi, R., A. M. Mortazavian, and A. G. Da Cruz. 2011. Viability of probiotic microorganisms in cheese during production and storage: A review. Dairy Sci. Technol. 91:283-308.

Kasımoğlu, A., M. Göncüoğlu, and S. Akgün. 2004. Probiotic white cheese with Lactobacillus acidophilus. Int. Dairy J. 14:1067-1073.

Kılıç, G. B., H. Kuleasan, I. Eralp, and A. G. Karahan. 2009. Manufacture of Turkish Beyaz cheese added with probiotic strains. Lebenson. Wiss. Technol. 42:1003-1008.

Krutulyte, R., K. G. Grunert, J. Scholderer, L. Lähteenmäki, K. S. Hagemann, P. Elgaard, B. Nielsen, and J. P. Graverholt. 2011. Perceived fit of different combinations of carriers and functional ingredients and its effect on purchase intention. Food Qual. Prefer. 21:361-367.

Luckow, T., V. Sheehan, C. Delahunty, and G. Fitzgerald. 2005. Determining the odor and flavor characteristics of probiotic, healthpromoting ingredients and the effects of repeated exposure on consumer acceptance. J. Food Sci. 70:S53-S59.

Luckow, T., V. Sheehan, G. Fitzgerald, and C. Delahunty. 2006. Exposure, health information and flavour-masking strategies for improving the sensory quality of probiotic juice. Appetite 47:315-323.

MacFie, H. J., N. Bratchell, K. Greenhoff, and L. V. Vallis. 1989. Designs to balance the effect of order of presentation and first-order carry-over effects in hall tests. J. Sens. Stud. 4:129-148.

Madureira, A. R., T. Brandão, A. M. Pintado, M. E. Gomes, and F. X. Malcata. 2011b. Technological optimization of manufacture of probiotic whey cheese matrices. J. Food Sci. 76:E203-E211.

Madureira, A. R., A. I. Pintado, A. M. Gomes, M. E. Pintado, and F. X. Malcata. 2011a. Protective effect of whey cheese matrix on probiotic strains exposed to simulated gastrointestinal conditions. Lebenson. Wiss. Technol. 44:75-81.

Majchrzak, D., B. Lahm, and K. Durrschmid. 2010. Conventional and probiotic yogurts differ in sensory properties but not in consumers' preference. J. Sens. Stud. 25:431-446.
Marcatti, B., A. M. Q. Habitante, P. J. A. Sobral, and C. S. F. FávaroTrindade. 2009. Minas-type fresh cheese developed from buffalo milk with addition of L. acidophilus. Sci. Agric. 66:481-485.

Marshall, R. T. 1993. Standard Methods for Examination of Dairy Products. American Public Health Association, Washington, DC.

Martín-Diana, A. B., C. Janer, C. Pelaéz, and T. Requena. 2003. Development of a fermented goat's milk containing probiotic bacteria. Int. Dairy J. 13:827-833.

Masuda, T., R. Yamanari, and T. Itoh. 2005. The trial for production of fresh cheese incorporated probiotic Lactobacillus acidophilus group lactic acid bacteria. Milchwissenschaft 60:167-171.

Medici, M., C. G. Vinderola, and G. Perdigón. 2004. Gut mucosal immunomodulation by probiotic fresh cheese. Int. Dairy J. 14:611618.

Melo, L. L. M. M., H. M. A. Bolini, and P. Efraim. 2009. Sensory profile, acceptability, and their relationship for diabetic/reduced calorie chocolates. Food Qual. Prefer. 20:138-143.

Milesi, M. M., G. Vinderola, N. Sabbag, C. A. Meinardi, and E. Hynes, 2009. Influence on cheese proteolysis and sensory characteristics of non-starter lactobacilli strains with probiotic potential. Food Res. Int. 42:1186-1196.

Modzelewska-Kapituła, M., J. A. N. Kobukowski, and L. Kłebukowska. 2010. The influence of feeding diets containing white cheese, produced with prebiotics and the potentially probiotic Lactobacillus plantarum strain, on the gastrointestinal microflora of rats. Czech J. Food Sci. 28:139-145.

Mortazavian, A. M., M. R. Ehsani, S. Sohrabvandi, and J. A. Reiheimer. 2007. MRS-Bile agar: Its suitability for the enumeration of mixed probiotic in cultured dairy products. Milchwissenschaft $62: 270-272$.

Obando, C. M., C. M. Brito, T. R. P. Schobitz, M. L. A. Baez, and R. M. Y. Horzella. 2010. Viability of the probiotic microorganisms Lactobacillus casei 01, Lactobacillus acidophilus La-5, Bifidobacterium BB12 during cottage cheese shelf life. Vitae 17:141-148.

Olson, D. W., and K. J. Aryana. 2008. An excessively high Lactobacillus acidophilus inoculation level in yogurt lowers product quality during storage. Lebenson. Wiss. Technol. 41:911-918.

Ong, L., and N. P. Shah. 2009. Probiotic Cheddar cheese: Influence of ripening temperatures on proteolysis and sensory characteristics of Cheddar cheeses. J. Food Sci. 74:S182-S191.

Ong, L., A. Henriksson, and N. P. Shah. 2006. Development of probiotic Cheddar cheese containing Lactobacillus acidophilus, Lb. casei, Lb. paracase $i$ and Bifidobacterium spp. and the influence of these bacteria on proteolytic patterns and production of organic acid. Int. Dairy J. 16:446-456.

Ortolani, M. B. T., P. M. Moraes, G. N. Viçosa, L. M. Perin, K. G. C. Lima, A. Silva-Junior, F. Sesma, B. D. G. Franco, and L. A. Nero. 2010. Molecular identification of naturally occurring bacteriocinogenic and bacteriocinogenic-like lactic acid bacteria in raw milk and soft cheese. J. Dairy Sci. 93:2880-2886.

Ouwehand, A. C., F. Ibrahim, and S. D. Forssten. 2010. Cheese as a carrier for probiotics: In vitro and human studies. Aust. J. Dairy Technol. 65:165-169.

Özer, B., and H. A. Kirmaci. 2009. Development of proteolysis in white-brined cheese: Role of microencapsulated Lactobacillus acidophilus LA-5 and Bifidobacterium bifidum BB-12 used as adjunct cultures. Milchwissenschaft 64:295-299.

Palazzo, A. B., and H. M. A. Bolini. 2009. Multiple time-intensity analysis and acceptance of raspberry-flavored gelatin. J. Sens. Stud. 24:648-663.

Pereira, L. C., C. H. B. Souza, J. H. Behrens, and S. M. I. Saad. 2010. Lactobacillus acidophilus and Bifidobacterium lactis in co-culture improve sensory acceptance of potentially probiotic petit suisse cheese. Acta Aliment. 39:265-276.

Perotti, M. G., D. J. Mercanti, S. M. Bernal, and C. A. Zalazar. 2009. Characterization of the free fatty acids profile of Pategrás cheese during ripening. Int. J. Dairy Technol. 62:331-338.

Pflanzer Junior, S. B., and A. G. Cruz., A. S. Sant'ana, M. R. L. Moura, L. M. J. Carvalho, and R. Silva. 2009. Food safety knowledge of Cheese consumers. J. Food Sci. 94:28-30. 
Polengui. 2011. Minas Frescal Light com Probióticos: Polenghi ajuda a deixar o dia-a-dia mais equilibrado. Accessed April 17, 2011. http: //www.polenghi.com.br//minas-frescal-light-com-probioticos.

Rodrigues, D., T. A. P. Rocha-Santos, C. I. Pereira, A. M. Gomes, F X. Malcata, and A. C. Freitas. 2011. The potential effect of FOS and inulin upon probiotic bacterium performance in curdled milk matrices. Lebenson. Wiss. Technol. 44:100-108.

Scheller, M., and D. J. O'Sullivan. 2011. Comparative analysis of an intestinal strain of Bifidobacterium longum and a strain of Bifidobacterium animalis subspecies lactis in Cheddar cheese. J. Dairy Sci. 94:1122-1131.

Sousa, M. J., Y. Ardö, and P. L. H. McSweeney. 2001. Advances in the study of proteolysis during cheese ripening. Int. Dairy J. $11: 327-345$.

Souza, C. H. B., and S. M. I. Saad. 2009. Viability of Lactobacillus acidophilus La-5 added solely or in co-culture with a yoghurt starter culture and implications on physico-chemical and related properties of Minas fresh cheese during storage. Lebenson. Wiss. Technol. 42:633-640.

Souza, T. B., A. G. Cruz, M. R. L. Moura, A. C. M. Vieira, and A. S. Sant'Ana. 2008. Microscopic quality indicators of Minas frescal cheese. Food Contr. 19:71-75.

Villanueva, N. D. M., and M. A. A. P. Da Silva. 2009. Comparative performance of the nine-point hedonic, hybrid and self-adjusting scales in the generation of internal preference maps. Food Qual. Prefer. 20:1-12.

Villanueva, N. D. M., N. Doris, and M. A. Trindade. 2010. Estimating sensory shelf life and carrot cupcakes using acceptance tests. J. Sens. Stud. 25:260-279.

Vinderola, C. G., P. Mocchiutti, and J. A. Reinheimer. 2002. Interactions among lactic acid starter and probiotic bacteria used for fermented dairy products. J. Dairy Sci. 85:721-729.

Vinderola, G., W. Prosello, F. Molinari, D. Ghiberto, and J. A. Reinheimer. 2009. Growth of Lactobacillus paracasei A13 in Argentinian probiotic cheese and its impact on the characteristics of the product. Int. J. Food Microbiol. 135:171-174.

Wang, H. K., C. Dong, Y. F. Chen, L. M. Cui, and H. P. Zhang. 2010. A new probiotic Cheddar cheese with high ACE-inhibitory activity and $\gamma$-aminobutyric acid content produced with koumiss-derived Lactobacillus casei Zhang. Food Technol. Biotechnol. 48:62-70.

Ziarno, M., D. Zarba, and A. Bzducha-Wrobel. 2010. Study on dynamics of microflora growth in probiotic rennet cheese models. Polish J. Food Nutr. Sci. 60:127-131.

Zomorodi, S., A. Khosrowshahi, S. M. R. Rohani, and S. Miraghaei. 2011. Survival of Lactobacillus casei, Lactobacillus plantarum and Bifidobacterium bifidum in free and microencapsulated forms on Iranian white cheese produced by ultrafiltration. Int. J. Dairy Technol. 64:84-91. 